\title{
Sino-Tibetan Language
}

National Cancer Institute

\section{Source}

National Cancer Institute. Sino-Tibetan Language. NCI Thesaurus. Code C161862.

A large family of languages spoken in China and from the Tibetan plateau in the north to the Malay peninsula in the south, and from northern Pakistan in the west to northeastern Vietnam in the east. 